\title{
5. Interpreting the Macassans: Language exchange in historical encounters
}

\author{
Paul Thomas
}

\section{Introduction}

The commencement of regular journeys by trepang fishing fleets out of Makassar to the Australian north coast in the second half of the eighteenth century represents the beginning of Asia's regular contact with Australia. The cyclical nature of the visits and the complexity of the engagement meant there was strong motivation for communication to take place, something that went beyond simple hand gestures and a smattering of borrowed words. For the first hundred years of these visits, this produced an exchange across the cultures and languages of Indonesians and Indigenous Australians. Subsequently, after the European discovery of the industry in 1803 and the desire to incorporate it into the colonial trading network, Europeans found they also needed to develop a capacity to freely converse with the trepangers.

This chapter focuses on the lives of three interpreters of Indonesian/Malay heritage who assumed the role of intermediaries between the Europeans and the trepangers during the nineteenth century. It is part of a broader history of communication between Australia and the Indonesian archipelago, which has ebbed and flowed through the decades but retained an inevitable trajectory towards a closer relationship. The fundamental questions of how Europeans initiated the communication, the motivation behind the exchanges, the influence of the languages chosen for the discourse, and the agency of the interpreters are examined within the context of the interpreters' biographies and Australia's relations with the archipelago at the time.

Most research on the industry to date has emphasised the significant cultural exchange between the Indonesians and Indigenous Australians and covers a broad range of topics including: the arts (Palmer 2007; Toner 2000); language (Evans 1997; Harris 1986); and religion (McIntosh 1996). In contrast, research on European Australian contact with the trepangers has been understandably narrower in focus, with an emphasis on the failed attempts at European settlements in northern Australia in the first half of the nineteenth century (see Reid 2007; Spillet 1972; Allen 2008); however, insights into European 
communication with the trepangers can be evidenced in Macknight's (1976) early pioneering work The Voyage to Marege', biographical reviews of George Windsor Earl, the interpreter at Port Essington settlement (Reece 1992), and writing on Collet Barker, the Commandant at Fort Wellington (Mulvaney and Green 1992; Mulvaney 1994). The overall evolution of this research is further explored in Macknight's chapter in this volume.

For Indigenous Australians, the possibility of cultural exchange was made possible through the ability to communicate at both the mundane and the abstract levels. Trade, an understanding of traditional law and the exchange of labour were crucial elements pressing those involved in the discourse to establish a common language; however, while it was not uncommon in nineteenth-century reports to describe Aborigines in the north as having a facility to speak Malay, the extent to which this was widespread remains unclear. A more likely scenario is that only a few had a substantial knowledge of the language of the visitors. The most likely candidates were individuals who sailed back with the Macassan fleet and resided there for one or more seasons, or the women who had longerterm relationships with the trepangers in Australia. These individuals were potentially the key conduits of cultural and language influence: Australia's first interpreters.

In the case of European contact with the trepangers, the selection of individuals to perform the duty of interpreter is more apparent, albeit an inconsistent process and obscured by the broader context. Interpreters are generally marginal figures within historical narratives, briefly referred to when there is a need to provide evidence that communication across cultures has truly taken place (see Roland 1999). The motivation behind these references commonly relates to the need to legitimise an action, to add credibility to a report or to prove justice has been provided. On those occasions when an individual involved in interpreting is referenced more fully, their role may still be subsumed into their other vocational activities, ${ }^{1}$ those acting exclusively as interpreters, even today, being the exception.

In order to provide greater context for the contact events with the trepangers, the three interpreters have been selected to reflect three distinct periods of the history: the European discovery of the industry; efforts to integrate the industry into the colonial economy; and finally, opposition to and eventual rejection of direct Indonesian involvement in the industry in the early twentieth century.

The three interpreters are from diverse backgrounds: Abraham Williams, a Javanese, who was working as a cook onboard Matthew Flinders' Investigator

1 'Natives', for example, are commonly recorded as guides or trackers, their interpreting role poorly revealed (Karttunen 1994). African slaves, granted the role of headman or teacher, often depended on their ability to act as interpreters to retain their positions (Fayer 2003). 
in 1803; Oodeen, of Ambonese/Sri Lankan background, who was appointed Government Interpreter for Fort Wellington between 1826 and 1829; and Tingha de Hans, a Timorese who settled in the Bowen Straits, Northern Territory, in the late nineteenth century. Of the three interpreters only Oodeen identified himself vocationally as an interpreter, the other two being more representative of the majority of interpreters in Australia in the nineteenth century who were part of an ad-hoc process, serving an immediate need.

The significance of viewing these individuals in their roles as interpreters is best appreciated through the manner in which the role elevated them into agents of influence and witnesses of historical events. As active participants in these events, they were involved in both the negotiation of meaning and the flow of ideas. While the ephemeral nature of the interpreting activity may not lend itself to linguistic analysis, the effectiveness of the interpreting, the subjectivity and perspective of the interpreter can be gleaned through their biographies, their interactions with others, and the information that resulted from the interpreting events. In this process, the interpreters themselves become historical figures, humanising further the act of interpreting or translation (see Pym 1998).

As with most Indonesians/Malays in Australia in the nineteenth century, there are few or no personal papers or diaries from the individuals themselves. This study, therefore, relies on a variety of documents in which the interpreters are incidental to the main purpose of the writing. The lack of the direct voice of the interpreter is not uncommon when dealing with interpreting history, but it should not negate investigating them as historical figures (Delisle and Woodsworth 1995, p. 245). Essentially, the influences on the interpreters' lives, their distance from the more authoritative figures at the centre of the events, and the focus on the moment of interpreting have considerable potential to enhance our understanding of the play of communication that takes place. $^{2}$

\section{Flinders and Williams: interpreting first contact with the 'Malays'}

When the British established the penal settlement at Port Jackson in New South Wales in 1788, they had no reason to believe there were outsiders other than themselves active on the continent. Neither Dutch nor British explorers had reported any activities beyond those of the Indigenous peoples. Flinders' discovery of Indonesian fishing praus off the north coast of Australia in February 1803 was, therefore, significant both from the perspective of the science of his

2 See Rundle (2011, p. 33) for a discussion on the relationship of translation history to historiography. 
exploration and for the potential commercial implications, the British East India Company being a major sponsor of the expedition. The discovery, however, could only be fully assessed if Flinders was able to report in detail the nature and scope of the activity. With no knowledge of any the archipelago's languages himself, he was reliant on his cook, Williams, to act as interpreter.

Williams, also referred to as Abraham Williams, ${ }^{3}$ has left little of his background to explore. There is no specific record of him joining the voyage, though Flinders' journal ${ }^{4}$ accounts for one cook, Joseph Robinott, and two cook's mates being taken aboard in London. His journal ${ }^{5}$ also describes Williams as being 'from the island of Java'; however, in his published account, he uses the more general term 'Malay' (Flinders 1814, p. 229). The term Javanese at the time could refer to someone from Batavia (Jakarta) in which case it would not be so much an ethnic identity as a geographical one. The Dutch also commonly referred to Indonesians in Sri Lanka or at the Cape of Good Hope as 'Javaansche' (Javanese), and Flinders, or Williams, could have been following the more general Dutch use of the word.

The possibility of a connection with South Africa, in particular, needs to be considered as Flinders already had some contact with the Cape through his previous voyages. This was also the period of the first British occupation of the Cape, which started in 1795. If Williams was born or had lived for a time in the Cape, it would strengthen the case for him having a more effective understanding of English and Malay than most Javanese of the period. It would also provide some indication of the variety of Malay he used. In the eighteenth century, Malay had developed as the main medium of instruction at the madaris (Islamic schools) of the Cape, and it generally replaced the regional languages amongst the diverse Indonesian diaspora. It was also a lingua franca of some prestige for other Asiatic groups (Stell 2007, p. 92). During the first British occupation, Malay was retained by the community, but there was also a spread of the English language and culture amongst many of the inhabitants to the degree that the Dutch Commissary, De Mist, wrote in 1802 that it would be 'the work of years to transform the citizens of Cape Town once again into Netherlanders' (De Mist in McCormick 2002, p. 23).

While it is difficult to piece together Williams' background, his use as an interpreter at the crucial meetings between Flinders and the nakhoda (captains of the fishing praus) makes him highly relevant to the event. Between 17 and 18 February 1803, the meetings with the nakhoda and Flinders can be defined

3 'Abraham' was first used in a publication by Ingleton (1986), but he offers no primary source to verify it. 4 Matthew Flinders, 26 January 1801, Journal on HMS 'Investigator', vol. 1, 1801-1802, Mitchell Library, State Library of New South Wales, Sydney, Australia [hereinafter ML]: MAV/FM3/763.

5 Matthew Flinders, 19 February 1803, Journal on HMS 'Investigator', vol. 2, 1802-1803, ML: MAV/ FM3/764. 
within four interpreting events. The first occurred shortly after the sightings of the praus when Captain Flinders ordered an armed whaleboat out to meet them, fearing them to be 'piratical Ladrones' ${ }^{6}$ Flinders, however, makes no reference to Williams being aboard the whaleboat, nor does any other journal except for that of seamen Samuel Smith, who states: 'On Opening the Harbour we espied 6 Sail laying at an Anchor, which we supposed to be China Junks, but upon nearer Observation they Proov'd Malay Prows. Sent a Boat on Board of one of them with an Interpreter, \& dropt our Anchr close to them' (Smith 1803 in Monteath 2002, p. 61).

This differs from Flinders' account, which suggests he only learnt that they were 'prows from Macassar' after the whaleboat returned. If the craft had been determined to be 'Malay' before the whaleboat had been sent out it is logical that Flinders would have sent Williams to interpret for his lieutenant. It would also explain how Flinders' lieutenant was able to communicate with the praus.

This first contact with the crew of the praus was a tense environment in which to interpret as there was a good deal of suspicion about each other's intent and both parties were armed. Flinders comments: 'Every motion in the whale boat, and in the vessel along-side which she was lying, was closely watched with our glasses' (Flinders 1814, p. 229). The first communication would have been further hampered by negotiations on which form of Malay to use and establishing the status of the speakers.

Having established peaceful relations, six Indonesian nakhoda came onboard the Investigator. Williams was then asked to interpret, which he did until sunset. The following morning, he was once again asked to interpret, this time accompanying Flinders with the botanist Robert Brown and the artist William Westall to the prau of $\mathrm{Pu}^{\prime}$ Baso'. This was followed by another session onboard the Investigator with the six nakhoda. In each session, Flinders showed his 'desire to learn everything concerning these people' (Flinders 1814, p. 230), and he admits that his 'numberless questions' had delayed Pu' Baso"s departure by a day (Flinders 1814, p. 232).

For Williams this could only have been an exhausting experience. Hours of interpreting would have taxed an experienced interpreter, whether they were familiar with the variety of language being used or not. In Williams' case, he almost certainly would have needed to constantly adjust his Malay to the variety of Malay used by the nakhoda. With possibly no interpreting experience previously, the intensity of the sessions, the discrepancy in different cultural views and the specialist nature of the vocabulary all would have added to the burden.

6 The term 'ladrones' (thieves) in this context was originally applied to rebellious Chinese by the Portuguese in Macao. The ladrones turned to piracy and were at their most menacing at the turn of the nineteenth century. 
Another important factor influencing the interpreting events was the level of Malay of the nakhoda. Flinders' primary source of information was $\mathrm{Pu}^{\prime}$ Baso' and Malay would not have been his first language. In this period, there were many in Makassar who had only a rudimentary knowledge of Malay, though those closer to the Court, which was a centre for translation from Malay (see Cummings 2009), and those who travelled widely, are much more likely to have a better grasp of the language. The nakhoda, particularly Pu' Baso', would have fitted into this latter category.

Remarkably, there is little mention by Flinders of any difficulties arising in the communication. The only critique comes from a short comment by Robert Brown, the expedition's botanist: 'Williams is but an indistinct interpreter' (Brown 1803 in Moore et al. 2001, p. 371). Brown had no knowledge of Malay himself, nor the process of interpreting, and so his critique would have been based mainly on the apparent flow of the conversation and the manner in which Williams conducted himself. This particular comment was related to some confusion over the use of the words 'timur laut' (northeast/seaward east) and the island of 'Timor', which was west of their position. While this may have kindled Brown's scepticism, it was not a problem of vocabulary. Rather, it suggests Williams was providing little explanation for his interpreting or simply was unaware of the geography involved.

Flinders' lack of critique, either in his log or in his published account, may suggest he was more tolerant of the process, but it also relates to the purpose of referencing Williams in the first place. Williams' position in Flinders' narrative was not as a key participant in the events, but as a tool by which he could validate the information in his report and to indicate that he had taken adequate care in its compilation.

We have no quotes from Williams himself and, therefore, know nothing directly about his response to the interpreting events or his relationship with Flinders, even though he was Flinders' personal cook. There is only the action of Williams, who upon the arrival of the Investigator in Timor absconded with 'a youth from Port Jackson' (Flinders 1814, p. 254). Flinders put some effort into tracking the men down and had the town searched, but with no result. Williams' value to the expedition must have risen considerably after the encounter with the trepangers, and his loss was clearly regretted. Perhaps the unreliability of his interpreter was a factor in Flinders himself deciding to learn Malay while under arrest on Mauritius. ${ }^{8}$ His intention was to return to the eastern archipelago, but it was a journey he never made.

7 The position related to the present Tanimbar group of islands.

8 Matthew Flinders, Journal, 2 June 1810, ML: CY 227. 
The extensive information that was derived from Williams' interpreting proved to be substantially correct and formed the basis of European discussion on the topic for more than a century. It also provides a strong contrast with those encounters where there was no interpreter. Phillip Parker King, who followed Flinders in 1818 to further survey the north coast of Australia, knew he was likely to encounter Indonesians on his journey, but instead of taking a Malay interpreter he carried with him two translated letters, one in Malay and the other in Javanese (see Figures 5.1 and 5.2). The letters had been prepared for him to secure safe passage by Sir Thomas Raffles, who had been the lieutenant governor of Java some few years earlier.

Unfortunately, when King did encounter the Indonesian praus near the Bowen Straits, on the north coast in April 1818, they had only symbolic value. The prau's crew could not read the Jawi script in which the Malay letter was written (see Figure 5.1) or the Javanese script (see Figure 5.2) of the accompanying letter. Flinders' meeting with $\mathrm{Pu}^{\prime}$ Baso' had shown that at least some of the fishers/traders were literate when Basso's son made notes during their meeting; however, they used the Bugis or Lontara script, a totally unrelated script.

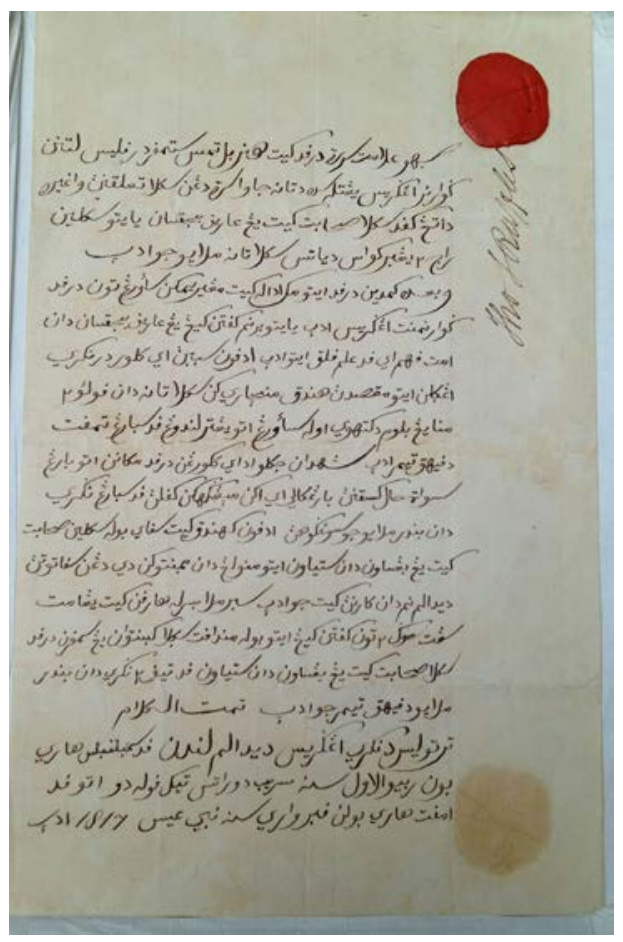

Figure 5.1 Letter of safe conduct written in Malay carried on the voyage of Phillip Parker King 


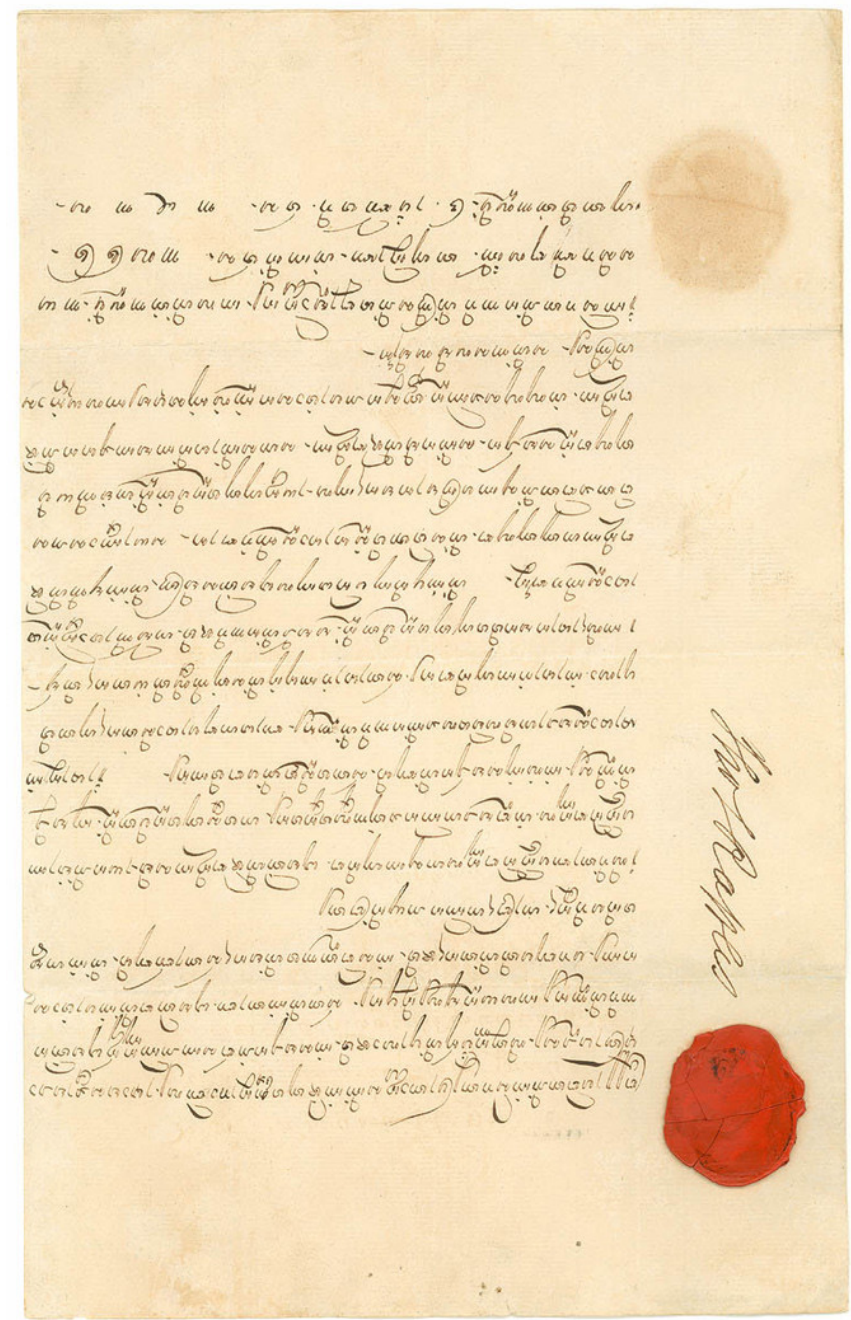

Figure 5.2 A version of the same letter in Javanese, also carried on the voyage

Source: Mitchell Library, State Library of New South Wales (MLMSS 6075)

The lack of knowledge by Europeans of the status of languages in the archipelago would persist throughout the nineteenth century and is emphasised by the comment of the botanist onboard King's ship, Allan Cunningham, who lamented that 'they were too illiterate to read their own language'. ${ }^{9}$ Consequently, the additional information gathered by King was mainly through his meeting with the Dutch in Kupang rather than directly from the trepangers.

9 Allan Cunningham, Journal, 25 April 1818, State Records Office of New South Wales, Australia [hereinafter SRNSW], 6034. 


\section{Oodeen: Diplomacy and trade in the north ${ }^{10}$}

The significance of the meeting between Flinders and the nakhoda became more apparent two decades after Flinders' circumnavigation, when the decision was made to settle northern Australia using the trepang fishing fleet as the catalyst for further trade. While the British signed a treaty with the Dutch in 1824 to delineate their claims on the archipelago, the north coast of Australia provided an opportunity to tap into the resources of the eastern archipelago and stave off any Dutch or French claims. There would be three successive attempts to establish a settlement and each settlement would take a different approach to communicating with the trepangers.

In the establishment of the first settlement at Fort Dundas on Melville Island in 1824 no provision for an interpreter was made; the Governor of New South Wales, Governor Brisbane, simply instructed the men of the garrison to 'learn their language, their customs, their usages, their institutions and pay a respect to them all' ${ }^{11}$ It is possible that there were some amongst the convicts and soldiers at the settlement who knew Malay, but as no trepangers ever called at the fort during its short life the language skills of its inhabitants were never tested.

In the second and third settlements, on the Cobourg Peninsula, an official government interpreter was appointed. At Fort Wellington, Oodeen, ${ }^{12}$ a former drum major in the Malay regiment in Sri Lanka, took up his position in 1827. In the third settlement, at Port Essington, George Windsor Earl became Government Interpreter in 1838. Earl had originally migrated to the Swan River Settlement in Western Australia to farm (see Jones 1994), but with no success he eventually sailed to Batavia and en route began learning Malay (Reece 1992, p. 3). He would spend several years in the archipelago gaining knowledge of several Austronesian languages before returning to Australia.

Unlike Earl, Oodeen has received little attention to date, though in recent years he has become a topic of interest for the Malay and Sri Lankan communities as an early Muslim pioneer. Knowledge of Oodeen has spread mainly through the work of a sixth-generation descendent of Oodeen, Glennys Ferguson (2002), and several Sri Lankan newspaper accounts (see Saldin 2003; Jayamanne 2003). These accounts have primarily been concerned with his earlier life in the military in Sri Lanka and in the family's migration to Sydney.

10 For an expanded account of Oodeen's biography and interpreting on which this section is based, see Thomas (2012).

11 Gov. Thomas Brisbane, Government House, Parramatta, 14 August 1824, Colonial Secretary's papers, in SRNSW 6013; 4/3512.

12 Variations of Oodeen's name include John and William, as his first name, with Odeen, Odean and O'Dean examples of surname variants. This chapter uses 'Oodeen' based on primary sources from Fort Wellington, the period most relevant to this history, and as a clearer guide to the original pronunciation. 


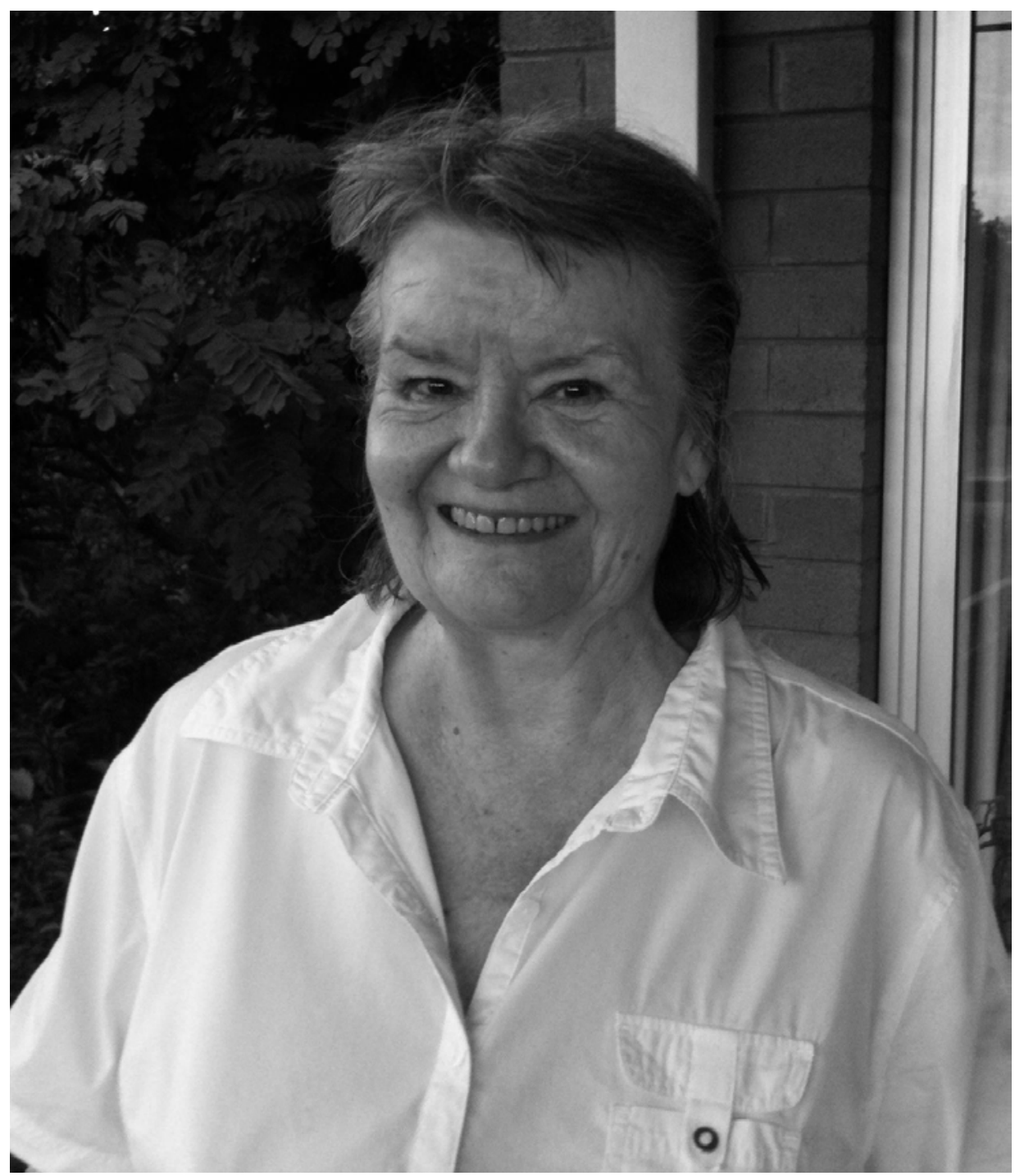

Figure 5.3 Glennys Ferguson of Sydney: sixth-generation descendent of Oodeen

Source: Paul Thomas

Oodeen arrived in Sydney in 1816, having survived frontline service with the Dutch Ambonese regiment, British Malay regiment and Kandyan armies. It was his defection to the Kandyans in 1803 that led to his eventual arrest and trial by the British in 1815 (Hough and Long 1825, p. 326). Oodeen was sentenced to death, but his sentence was commuted to transportation to New South Wales in respect of the wishes of the Sri Lankan Malay regiment whom the British were trying to develop into loyal troops (Thomas 2012, p. 127). 
He arrived in Sydney with his wife, Eve, and their three children, a privilege not afforded to all convicts, but an additional concession made after the trial. The Sydney Gazette (17 February 1816, p. 1) described him as 'dark complexioned, approaching to a black, and is about 5 feet 10 inches in height' and as a man 'who appears to be intelligent'. It was emphasised that his wife was 'Singhalese, being a true descendant of the aboriginal inhabitants of the island'. In Sydney, Oodeen was given duties as a night watchman on the docks. He was quick to secure the trust of those he worked with to the extent that by 1818 he requested and was granted a ticket-of-leave, allowing him the freedom to apply for other positions. ${ }^{13}$ It was at this time that the position of government interpreter at Fort Wellington was offered to him.

Oodeen's suitability for the position was relatively clear, as in addition to speaking Malay: he was literate, though it is unclear to what degree in English; he had experience serving with the British military; he was acclimatised to tropical postings; and he was familiar with other languages, most likely Sinhalese and Tamil, useful for a port that aimed at linking Australia, the Malay/Indonesian Archipelago and India. Another aspect that would have made Oodeen an attractive choice was his religion. Flinders had remarked that the trepangers were 'Mohammadeans' and Oodeen's presence had the potential to demonstrate British tolerance to the Muslim traders from Makassar. In the opening of any interpreting event, it would have also allowed Oodeen to at least greet the nakhoda with the universal Islamic greeting, thus providing some initial familiarity before negotiating the form of Malay to use. While his religion is not mentioned by the commandants of Fort Wellington, Oodeen had brought the first recorded Qur'an to the colony of New South Wales and on his return to Sydney would be employed as a court interpreter, swearing in Muslims appearing before the courts. ${ }^{14}$

The decision to employ Oodeen as a government interpreter was motivated by the need for diplomacy and to demonstrate a legitimate desire to develop trade. There was also a desire to promulgate the pre-eminence of the British over the Dutch: 'Let the Indian taste on the shores of New Holland for the first time in his life the sweets of private prosperity.' ${ }^{\prime 15}$

Oodeen arrived at Port Raffles in 1827 at the age of fifty-four, which would have made him one of the elders of the settlement. He had been offered a wage of $£ 70$ per year, supplies and permission to establish his own house. ${ }^{16}$ Ostensibly, this was a substantial improvement from the conditions he was working under

13 Petition for mitigation of sentence, 5 December 1818, Colonial Secretary Papers, SRNSW: 3189, 4/1856.

14 Sydney Gazette and New South Wales Advertiser, 26 January 1836, p. 3.

15 Governor Brisbane, 14 August 1824, SRNSW, 6013; 4/3512, pp. 240-1.

16 Returns of the Colony, 1828, SRNSW, 4/257, pp. 96-7. 
in Sydney and it was a real opportunity for him to settle his family and regain some of his dignity. The rudimentary and fragile nature of the settlement is likely to have been of lesser concern.

Oodeen's interpreting at Fort Wellington was in complete contrast with that of Williams on the Investigator. Whereas Williams interpreted intensively over two days with little time to adapt his language, Oodeen acted as interpreter across two trepang fishing seasons: 1828 under Captain Henry Smyth, and 1829 under Captain Collet Barker. This allowed him to derive a considerable amount of experience from the interpreting events he took part in.

Oodeen's first act as an interpreter occurred seven months after his arrival when a prau was sighted at the mouth of the harbour of Palm Bay. Oodeen was dispatched with a letter from Captain Smyth and tasked with enticing the prau to call at the port. Oodeen was successful, leading to the first meeting between Captain Smyth and the nakhoda of the prau, Dieng Riolo. Although Smyth had failed in his communication with the Cobourg Peninsula Aborigines, through Oodeen he had the opportunity to develop a more successful relationship with the trepangers. His first impressions of the nakhoda Dieng Riolo were clearly positive: 'he is a most polite, graceful Malay and made us several presents.' ${ }^{17}$ Smyth in turn presented Dieng Riolo with a 'Hogshead Cast'. ${ }^{18}$

The exchange of gifts was a feature of a number of meetings between the nakhoda and the commandants of Fort Wellington. The exchanges were not the commencement of trade, but aspects of cultural etiquette essential to the beginnings of diplomacy and an area in which Oodeen was expected to be of some assistance.

In a meeting between a nakhoda and the new Commandant of Fort Wellington, Captain Collet Barker, during the trepang season of 1829, Oodeen was asked to decline a simple gift of rice on behalf of Barker: 'Some of the Captains wanted to make me a present of some rice, which they said was the only thing they had at present, but I declined as civilly as I could, desiring the interpreter to say I did not wish or expect anything from them' (Mulvaney and Green 1992, p. 139). ${ }^{19}$ This was, predictably, not possible, and most likely on Oodeen's advice Barker accepted a coconut and some tortoise shell as a substitute.

While Oodeen may not have been fully aware of the nature of Bugis or Makassarese customs, his religious and cultural background would have contributed to his intuitive sense of ritual in these early meetings. Barker in his diary acknowledges

17 Sydney Gazette and New South Wales Advertiser, 11 July 1828, p. 2.

18 Captain Smyth to Colonial Secretary Macleay, 20 March 1828, Historical Records of Australia [hereinafter HRA], 3.6, p. 789.

19 Mulvaney and Green's (1992) transcription of Collet Barker's diary is used in this chapter for ease of reference. Barker's original papers from Fort Wellington can be sighted in Collet Barker Papers, ML: A2002. 
the need to sometimes defer to Oodeen in these circumstances when he recounts an intention to visit only one of several praus that were in port but 'found from the interpreter I should offend the others if I did not also visit them \& I went to all, sitting a short time with each in a small cabin thatched above like the roof of a house' (Mulvaney and Green 1992, p. 136).

There were, however, areas in which Oodeen was less likely to be of assistance, such as those related to the terminology of ships or maritime navigation. Oodeen had never served at sea and Williams may well have had an advantage over Oodeen in this area. This lack of knowledge could be further compounded when specific cultural and technical differences emerged during an interpreting event. When Captain Barker, for example, questioned the nakhoda Narrein about his navigation of northern waters, Narrein became confused with Barker's use of a chart of some of the nearby bays. He explained he did not understand the charts but Barker became frustrated: 'nor could I through the interpreter explain it' (Mulvaney and Green 1992, p. 135). In this case it is likely that Oodeen was just as confused as Narrein.

Although in the reported interpreting events the trepangers seemed prepared to answer whatever questions they were asked, it cannot be assumed that they were always eager to part with their knowledge. They were not naive to the rivalry between the Dutch and the English and they carried their own suspicions regarding possible taxes or duties that the British might wish to impose. One nakhoda was sent by the Dutch to specifically inform them on the state of Fort Wellington (Overweel 2002, p. 9). Essentially, the trepangers would have had occasion to consider their responses carefully and this in turn had the potential to slow or confuse the communication, consequently influencing Oodeen's ability to interpret freely.

Ultimately, the greatest challenge to Oodeen remained the varying Malay dialects and the degree to which the trepangers from Makassar could effectively use them. This may have eroded some of the advantage of the frequent interpreting he was engaged in and may have induced Barker's comment: 'I think the interpreter does not understand their language thoroughly' (Mulvaney and Green 1992, p. 137). This doubt over Oodeen's ability was only recorded once in Barker's diary and it is unclear whether it was specific to an event or a language. Barker, presumably informed by Oodeen, could determine that there was more than one language at play, noting after an interpreting event: 'one of them did not speak Malay, but only the Macassan tongue'20 (Mulvaney and Green 1992, p. 160).

Despite the possible shortcomings in Oodeen's knowledge of the languages in use, Barker continued to use Oodeen as an interpreter until it was ordered the

20 It is likely that Barker was referring to the use of Bugis or Makassarese, which along with Malay were used by the mixed crews from eastern Indonesia. 
settlement be abandoned in August 1829. There had been a proposal to replace Oodeen with another Malay speaker of Sri Lankan origins, a convict accountant named Jean Herman Maas; ${ }^{21}$ however, this was related to Oodeen's journey back to Sydney to escort his family to the settlement, which occurred before Captain Barker's arrival at Fort Wellington. Causing some confusion, Oodeen's family had departed before he could reach Sydney. On arrival, he was ordered to remain there. Distraught at the separation from his family, he made a personal appeal to the governor, offering to take a reduction in pay, which the Government accepted, and he returned to Fort Wellington. ${ }^{22}$

After the trepang season had finished and the settlement was abandoned, Oodeen was returned to Sydney. There he continued to act as a court interpreter, mainly for lascars, ${ }^{23}$ late into his life, dying at the age of eighty-seven 'a respected colonist' ${ }^{24}$ If the objective in employing Oodeen at Fort Wellington was to convey a genuine desire to communicate, a willingness to negotiate and an overall intent of goodwill on behalf of the British, it was an objective clearly achieved. Both Barker and Oodeen would have been aware that this goodwill would now be at risk when the trepangers returned the following season, perhaps with a cargo ready to commence trade. The relationship, however, would be rebuilt 10 years later when Port Essington was settled in 1838 and George Windsor Earl arrived to interpret. Once it too was abandoned, ${ }^{25}$ however, consideration of the trepangers would move to the margins of northern development and consequently the communication with them becomes more obscure and less direct in the historical record.

\section{Tingha de Hans and the end of the 'Macassans'}

Unlike the settlements in the first half of the nineteenth century, with the establishment of Palmerston in 1869, later renamed Darwin, there was no intention of relying on links with the trepang fishers for its commercial development; pearling, cattle and the establishment of a telegraph station were of much greater interest. The trepangers, however, were not ignored and tension began to rise over how the colony of South Australia, which now had authority over northern waters, could manage the fishery. The amount of duties that could be levied and European entry into the industry led to questions on whether

21 Captain Warteen, Colonial Secretary Letters sent to Fort Wellington 1827-29, SRNSW 4/3731.

22 William O'Deane to Governor Darling, 14 November 1828, Colonial Secretary's Letters, SRNSW, 4/2000.

23 Lascar here refers to seamen from the Indian subcontinent, though the term was also applied to those from the Malay Archipelago.

24 Sydney Morning Herald, 24 May 1860, p. 1.

25 The settlement lasted approximately 10 years, abandoned in 1849. 
the Makassar-based fleets should have any further part in it at all. Occupying a space that overlapped these two worlds was an Australian-based Timorese trepanger, amongst a number of other occupations, who was both proficient in Malay and English and had ability in the Indigenous dialects of the Cobourg Peninsula.

Tingha de Hans $^{26}$ arrived in Darwin from Kupang in West Timor in the first half of the 1870s. He was in his early twenties and started work as a domestic servant. The earliest record of his presence in Darwin relates to a court case in 1874 between a Mrs Catherine Cox and her Malay servant, Mita Ab Doolak, who Mrs Cox accused of deserting her service. In a series of accusations and counteraccusations arising from the case, Tingha appeared as one of several men accused of having slept with Mita. Fortunately for Mita and Tingha, Mrs Cox's accusations were found improbable and both Tingha and Mita had their names cleared. Relevant to Tingha's future role as an intermediary, there is no record of an interpreter being used, suggesting that Tingha already had sufficient English to negotiate his case in the court system.

Described as 'a well educated fellow' (Searcy 1912, p. 160), 'shrewd and intelligent', ${ }^{27}$ of 'sturdy build...an exceptionally sober and steady man', ${ }^{28}$ Tingha also appears to have been competitive and determined. In 1882, he won a Darwin running race against an overly confident professional runner, Rodney Spencer, who offered him a 7-yard start in a 50-yard race; Tingha pocketed $£ 15$ for his effort. ${ }^{29}$ In 1898, as a buffalo hunter, he tallied the highest number of hides, well more than 1000, though it was claimed he started earlier than the rest of the hunters. ${ }^{30} \mathrm{He}$ worked both independently and under the employ of others, building up sufficient funds so that by the 1890s he was able to order an 8 t lugger from Hong Kong.

Crucial to his enterprise and a feature that set him apart from most other pioneers in the Territory was his ability to communicate across a number of cultural and linguistic boundaries. While there are scant accounts where the term 'interpreter' is applied to Tingha, in reports that provide the context of his activities it is often implied or assumed. His interpreting is masked by the task at hand, such as the trading and trepanging, and because he was never paid to interpret. Interpreting was a talent that he offered as part of his general duties or used for his own benefit. Nevertheless, over his lifetime he was probably involved in more ad-hoc interpreting than either Williams or Oodeen.

\footnotetext{
26 Also Tingga and Tènga (Cense 1952), the last being based on pronunciation is likely to be the most accurate.

27 Northern Territory Times and Gazette, 31 March 1905, p. 3.

28 ibid., 16 February 1906, p. 3.

29 ibid., 11 March 1882, p. 2.

30 ibid., 4 November 1898, p. 2.
} 
Beyond Tingha's individual context, the preference for pearling and other industries changed the nature of the relationship between the authorities and the trepangers from one that previously required diplomacy, persuasiveness and the building of trust, to one in which the rules of law were dictated. Rather than encouraging Indonesian participation in the industry, new regulations and customs duties contributed to a decrease in the fishing fleet size and constrained the development of further trade. A government interpreter was seen as an unnecessary cost in terms of the day-to-day implementation of this policy, particularly as the consequences of poor communication were mainly borne by trepangers.

Additionally, formal communication from the South Australian authorities bypassed the nakhoda all together, instead moving between the colonial authorities in Adelaide and Makassar via the Dutch consul. This reduced further any pressure for official interpreters and translators, as the South Australians simply wrote in English, leaving it to the Dutch to translate into Dutch or Malay. Under these circumstances, the nakhoda and the owners of the praus were left to negotiate through the authorities in Makassar (Macknight 1976, p. 108). This created communication that was bureaucratic, aloof and tainted by inter-colonial rivalry.

Even when E. O. Robinson, the first customs official appointed for the Cobourg Peninsula, made a recommendation that the regulations be translated into Malay, it was never acted upon. Admittedly, it would have been difficult in terms of choosing an appropriate written form as not all the nakhoda were necessarily literate in either Arabic or the Latin-based scripts. ${ }^{31}$ Nevertheless, an official such as Robinson, who eventually learnt some of 'the Makassar language', 32 would have been able to read the translation out aloud, permitting a more confident and consistent message to be transferred.

The usefulness of having an interpreter was appreciated by Alfred Searcy, the Darwin based Sub-Collector of Customs, who visited the trepang fisheries aboard the Flying Cloud in 1883. He ensured that the new customs regulations were understood by relying on his Malay serang (boatswain) as an interpreter. In a meeting with the nakhoda Ban Kassi, he explains: 'Thro' the serang I informed Ban Kassi of the regulations made by the Govt. of South Australia with regard to trepang fishing' (Searcy 1907, p. 69). The serang was from Makassar, potentially allowing him to become a very useful interpreter. The crew on the Flying Cloud

31 Macknight suggests the Makasar language (Makassarese) may have been more useful (1976, p. 105), though once again not all the nakhoda or the owners of the praus spoke Makassarese or Bugis and, in any expansion of the trade, Malay would have had greater currency in the archipelago.

32 Northern Territory Times and Gazette, 22 November 1917, p. 23. The 'Macassar language' in this context may not be a precise reference to any particular language or dialect but rather to whatever language the trepangers from Makassar were using. 
had been recruited from Surabaya, but the serang's Makassar origins must have been seen as an advantage in regards to his ability to communicate with the trepangers.

Unfortunately for Robinson, the Flying Cloud was based in Darwin and while Searcy organised a customs officer uniform and a revolver for Robinson, the collector was left to his own devices in regards to the language. It is here that Tingha's move to the new Revenue Station at Bowen Straits in 1884 cannot be considered accidental or purely in the context of buffalo hunting, which he also did for Robinson. Tingha and Robinson developed a longstanding relationship that lasted more than 15 years and there was considerable trust between the men. On occasions, Robinson left Tingha to manage the Revenue Station (Searcy 1907, p. 212), even though he had no official status in regards to customs. Tingha could be trusted to act as a go-between, receiving and passing on information between Robinson and the trepangers. If Robinson was away, the interpreting process would be delayed, the movement from one language to another hidden by the interlude; the information, as one report noted, 'filtered'33 by Tingha.

At the Bowen Straits Revenue Station, Tingha developed his relationship with the visiting trepangers and no doubt he would have become acquainted with their language as well as the varieties of Malay used on board the praus. This would have led to the incorporation of its vocabulary into their exchanges as his contact with them matured, particularly in informal conversation; however, Malay would have retained its usefulness in more formal or complex communication. Malay was not simply a lingua franca, but it conveyed some prestige and authority to the speaker.

By the turn of the twentieth century, Malay had increasing currency in the eastern archipelago and more of the nakhoda would have been familiar with it than had been experienced by either Williams or Oodeen. Additionally, Tingha's Kupang Malay would have been a more familiar variety to those on the fishing fleet than the Malay of Williams or Oodeen. Kupang was settled by Indonesians from Ambon, Timor, Rote, Solor and Sabu in the eighteenth century and this consolidated the role of Malay as a lingua franca on Timor, though localisation of the language still made it distinct (see Grimes and Jacob 2006).

Without a record of Tingha's day-to-day duties at the Revenue Stationneither Robinson nor Tingha has left a diary - the specifics of Tingha's role as an interpreter is largely unknown, though some understanding can be drawn through incidental accounts related to other matters, notably court cases. In a case investigating the killing of five shipwrecked Indonesians near the Bowen Straits in 1892, one of the defendants, Mangerippy, testified: 'at first the Malays 
spoke, but we did not understand and they then said "Tingha" and pointed towards the Bowen Straits. ${ }^{34}$ In fact, the murders were first brought to the attention of the authorities through Tingha, who passed the information on to Robinson, who then relayed it to Searcy. ${ }^{35}$ The incident illustrates the role of Tingha as a point of first contact, not only between the visiting trepangers and Robinson, but also in the negotiations between Aboriginal Australians and the Indonesians.

In the 1880s, Tingha had settled with an Aboriginal woman known as Maryanageene. Searcy described her as 'a remarkably handsome native wife, a half caste Malay girl, full of fun and frolic' (1912, p. 160). Maryanageene would have been a key link to the local Aboriginal community for Tingha and influenced greatly his use of the local language, which he was able to speak to some extent. This is most likely to have been Iwaidja, which was used amongst Aboriginal people as a lingua franca in early industries on the Cobourg Peninsula (see Evans 2000). Tingha's good relationship with the Aborigines was admired by some in the Territory: 'Tinggha probably possesses more intimate and thorough knowledge of the native character than any other man in the territory.' ${ }^{36}$ There was also a degree of jealousy of his success in being able to employ them: 'and [he] seems to have possessed a happy knack of getting along with the coastal natives, who would work for Tingha when they would work for no one else. ${ }^{37}$ While Robinson was eventually capable of communicating with the trepangers to a limited degree himself, the man who followed him in 1899, Alfred Brown, was much more reliant on Tingha both as an interpreter and as someone who understood the fishery. He had no knowledge of the area ${ }^{38}$ but was reassured by the promise of Tingha's assistance (Macknight 1976, p. 119).

The most explicit reference to Tingha's use as an interpreter by Brown comes from what was reported as the killing of another shipwrecked crew in 1902. The murders purportedly occurred in an extremely isolated part of the coast, however, the case was brought to the attention of the Dutch consul and this escalated the incident. The case grew further in complexity as the new Commonwealth of Australia ${ }^{39}$ challenged the authority of what was now the State of South Australia over the matter.

Information about the murders relied on a lone survivor, a man called Ahmet, also known as Lau Batoe, who recounted how their vessel struck bad weather and was disabled. It was adrift for 29 days before becoming completely

34 ibid., 18 November 1892, p. 3.

35 ibid., 17 February 1893, p. 3.

36 ibid., 31 March 1905, p. 3.

37 ibid., 16 February 1906, p. 3.

38 See Brown's examination in Dashwood (1902).

39 The six Australian colonies had federated into the Commonwealth of Australia only 12 months previously and the Commonwealth's powers were still poorly understood. 
wrecked in the English Company's Islands, near Cape Wilberforce. The crew was forced to rescue what they could of their supplies and take refuge on a beach. Marooned, the shipwrecked sailors were approached by two Aborigines requesting rice and who remained with them for two days, the sub-collector of customs' report explaining that the Aborigines were able to use Malay to communicate with them. Three days after the two Aborigines departed, a larger group of Aborigines arrived and Ahmet claimed that it was then that his fellow crewmembers were speared and clubbed. ${ }^{40}$

In Brown's report to the Sub-Collector of Customs in Darwin, William George Stretton, he was explicit about the use of Tingha as an interpreter: 'I have interviewed the survivor and with the assistance of Tinga de Hans as interpreter, have obtained the following particulars. ${ }^{41}$ With such sensitivities related to the legal particulars of the case and the issue of compensation being raised, the need to be able to trace the veracity of the information was critical. It is not surprising, therefore, that statements related to Tingha's interpreting were repeated through many of the relevant documents. Neither the act of interpreting nor the identity of the interpreter was obscured, rather they were formally proclaimed. In doing so, credibility and due process were heralded to the reader.

As the matter proceeded, the verity of Ahmet's statement came under scrutiny, leading to further exchanges between the Dutch, Commonwealth and State governments. The Commonwealth's dissatisfaction with the flow of information would eventually result in the Australian prime minister, through the governor-general, complaining to the British prime minister, ${ }^{42}$ 'emphasising the necessity...for referring the constitutional questions involved to the High Court of the Commonwealth as soon as possible after its establishment' ${ }^{43}$

At the same time that these investigations proceeded, both Tingha and Brown were examined for a Commonwealth report on pearling and trepanging in northern Australia conducted by Justice Dashwood (1902). Tingha was interviewed as a trepanger in his own right, but he was also being questioned on the opinion of the Indonesian trepangers, there being no intention to interview them directly. He is asked why their numbers have dropped, how they get their trepang, and about their difficulty of paying with sovereigns. The interview, as reported, is short but the selection of Tingha is indication of the respect for Tingha's role in the industry and his links with the Indonesian trepangers. Justice Dashwood already had Brown's account of the industry in the Bowen

40 Extract of the report by the Sub-Collector of Customs, Port Darwin, National Archives of Australia [hereinafter NAA], 1903/6187.

41 Ibid.

42 The United Kingdom still moderated much of Australia's overseas relations, including its relationship with the Dutch East Indies.

43 Governor-General Chamberlain to the British Prime Minister, Lord Tennyson, 7 August 1903, NAA, A1 $1903 / 6187$. 
Straits but Tingga acts as an interpreter for the industry in both the narrow and the broader senses of the word; he is seen as a reliable intermediary through which information can pass.

As with both Williams and Oodeen, we know little of what the visiting Indonesians thought of Tingha's role other than that they actively sought him out and that he was remembered long after the annual visits were prohibited. In the 1950s when Daeng Sarro, a former nakhoda with the fishing fleets, was interviewed in his home near Makassar by a Dutch scholar, Tingha was one of the few individuals clearly identified (Cense 1952).

Tingha died in the Bowen Straits at the age of fifty-three on 24 January 1906, the same year that the South Australian Government decided to cease issuing licences to the fishers. His lugger and goods were auctioned off by Brown, but it took some time before his family heard the news. His three brothers did not arrive from Kupang until 1910 to settle the estate ${ }^{44}$ and it is unclear whether there were any funds left. With the death of Tingha, the last significant contact between European Australians and the independent Indonesian trepangers was cut. Clearly, with the implementation of the new laws there was no real need to look for a replacement.

\section{Conclusion}

European Australian contact with the Indonesian trepangers lasted just more than a century. It started with great expectations of trade and cooperation, though in time the relationship withered and was brought to a deliberate end as colonial boundaries became less negotiable, alternative commerce seemed more viable and Australia's cultural view of itself emerged as strictly European. When the Australian colonies were reborn as the Commonwealth of Australia in 1901, the new nation accepted its dependence on British capital and diplomacy and felt no immediate pressure to communicate with its neighbours to the north.

In international negotiations, the new Commonwealth deferred to the British to the extent that contact with the Dutch East Indies was moderated via London and any direct exchange with the 'natives' of the Indonesian archipelago was left to the pearlers and adventurers. From the Government's perspective, it preferred to cocoon itself within an English-speaking dominion, despite the persistence of a diversity of languages in its marginal migrant and Indigenous communities.

44 Northern Territory Times and Gazette, 2 September 1910, p. 3. 
Williams', Oodeen's and Tingha's roles as interpreters provide an alternative history to this isolated perspective. Their lives covered a period of changing responses to Australia's contact with the archipelago. In the first half of the nineteenth century, Williams and Oodeen interpreted in an environment tempered by influences of the Enlightenment and by a technological gap that was not so severe. Macknight (2011, p. 122) makes the point that in this period 'there was much in common between the world of the observers [the British] and that of the trepangers'. They both 'depended upon and were intimately familiar with the operation of sailing vessels, as were the trepangers...Similarly, other aspects of technology, especially guns, and of social and economic organisation were not widely divergent'. In contrast, the Northern Territory of Tingha's time was seeking a far more complex engagement with the world. It was perhaps overly ambitious and under resourced, but its dream of commerce and industry encouraged greater distance from the Indigenous cultures of the north and those of the archipelago.

By revealing the interpreting role of the three men, the voice of the Indonesian fishers and traders is brought into closer proximity with the historical events in which they were participants. It also presents another perspective on the betterknown figures the interpreters were associated with: Flinders with Williams, Smyth and Barker with Oodeen, and Robinson and Brown with Tingha. More importantly, the presence of the interpreter is a reminder that what was reported was moderated and filtered by the motivation of those who engaged the interpreters, as well as the constraints and subjectivity of the interpreters.

The biographical references of Williams, Oodeen and Tingha indicate they were independent agents, unlikely to act in an overly subservient way. In the case of Oodeen and Tingha, they were clearly intelligent and determined individuals, characteristics that need to be considered when assessing them as adaptable linguists, capable of going beyond their own language and culture. Further research is still required to pull together the scattered and veiled evidence of these men's roles as interpreters. It would be useful to know more about Williams' origins, Oodeen's religious knowledge and Tingha's role as an arbitrator in conflicts between Aboriginal Australians and the Indonesians. Knowledge of their use of varieties of Malay also remains more deductive, though the remarkable versatility and geographical spread of the language in the nineteenth century are clearly demonstrated.

Deficiencies aside, the interpreters' histories provide a view from the margins and the centre of events, inhabiting both the European culture of their employ and the Indonesian culture of their inheritance. Had they not been present we would be left to ponder their absence as Cunningham, the botanist on Phillip Parker King's voyage, did in 1818: 'Most valuable information might be obtained 
from these Asiatics as to their seasons of fishing and detention on this coast, the success of their fisheries, the value of their cargoes, their opinion of the natives, could we have conversed with them through the medium of an interpreter. ${ }^{\prime 45}$

Cunningham's wistful comment arises out of his desire for real contact with 'these Asiatics' and ultimately brings to the fore the priority of human interaction in exploration and the potential of the interpreter to engender it.

\section{References}

Allen, J. (2008) Port Essington: The historical archaeology of a north Australian nineteenth-century military outpost, Sydney: Sydney University Press.

Cense, A. A. (1952) 'Makassaars-Boeginese Prauwvaart op Noord-Australië', Bijdragen tot de Taal-, Land-en Volkenkunde uitgegeven door het Koninklijk Instituut voor Taa-, Land-en Volkenkunde, 108, pp. 248-64.

Cummings, W. (2009) 'Garis Luar Penerjemahan di Makassar', in H. ChambertLoir (ed.), Sejarah terjemahan di Indonesia dan Malaysia, Jakarta: Kepustakaan Populer Gramedia, pp. 273-84.

Dashwood, C. J. (1902) 'Report by His Honour Judge Dashwood, government resident, Palmerston on the pearl-shelling industry in Port Darwin and Northern Territory', Commonwealth Parliamentary Papers-1901-1902, House of Representatives, Melbourne: Commonwealth of Australia.

Delisle, J. and J. Woodsworth 1995. Translators through History. Philadelphia: John Benjamin's Publishing Company.

Earl, G. W. (1846) 'On the Aboriginal tribes of the north coast of Australia', Journal of the Royal Geographical Society, 16, pp. 239-51.

Evans, N. (1997) 'Macassan loans and linguistic stratification in western Arnhem Land', in P. McConvell and N. Evans (eds), Archaeology and Linguistics: Aboriginal Australia in global perspective, Melbourne: Oxford University Press, pp. 237-60.

Evans, N. (2000) 'Iwaidjan, a very un-Australian language family', Linguistic Typology, 4, pp. 91-142.

Fayer, J. (2003) 'African interpreters in the Atlantic slave trade', Anthropological Linguistics, 45 (3), pp. 281-95.

45 Allan Cunningham, Journal, 25 April 1818, SRNSW, 6034/SZ7. 
Flinders, M. (1814) A Voyage to Terra Australis undertaken for the Purpose of Completing Discovery of that Vast Country, and Prosecuted in the Years 1801, 1802, and 1803, London: G. \& W. Nicol.

Ferguson, G. (2002) 'The first Ceylonese family in Australia', Ceylankan,the Ceylon Society of Australia, 5 (1), pp. 14-18.

Fox, J. J. (2003) 'Tracing the path, recounting the past: historical perspectives on Timor', in J. J. Fox and D. Soares (eds), Oceanic Explorations: Lapita and western Pacific settlement, Canberra: ANU E Press, pp. 1-27.

Grimes, B. and J. Jacob (2006) Developing a role for Kupang Malay: the contemporary politics of an eastern Indonesian creole, Tenth International Conference on Austronesian Linguistics, Linguistic Society of the Philippines and SIL International, <http://www.sil.org/asia/philippines/ical/papers. html $>$ [viewed 3 February 2012].

Harris, J. (1986) Northern Territory Pidgins and the Origin of Kriol, Series C, Canberra: Pacific Linguistics.

Hough, C. and G. Long (1825) The Practice of Courts-martial, also the Legal Exposition and Military Explanation of the Mutiny Act, and Articles of War, London: Kingsbury, Parbury \& Allen.

Ingleton, G. (1986) Matthew Flinders: Navigator and chartmaker, Guildford, UK: Genesis Publications in association with Hedley Australia.

Jayamanne, F. S. R. (2003) 'Anecdotal account of the lst Ceylonese soldier migrant to Australia: pioneer, not convict', Sunday Observer, 29 June, <http://www. sundayobserver.lk/2003/06/29/feal4.html> [viewed 12 April 2011].

Jones, R. (1994) 'Out of the shadows: George Windsor Earl in Western Australia', Indonesia Circle, pp. 265-78.

Karttunen, F. (1994) Between Worlds: Interpreters, Guides, and Survivors, New Brunswick, NJ: Rutgers University Press.

McCormick, K. (2002) Language in Cape Town's District Six, Oxford: Oxford University Press.

McIntosh, I. (1996) 'Islam and Australia's Aborigines? A perspective from northeast Arnhem Land', Journal of Religious History, 20 (1), pp. 53-77.

Macknight, C. (1976) The Voyage to Marege': Macassan trepangers in northern Australia, Carlton, Vic.: Melbourne University Press. 
Macknight, C. (2011) 'The view from Marege': Australian knowledge of Makassar and the impact of the trepang industry across two centuries', Aboriginal History, 35, pp. 121-43.

Monteath, P. (2002) Sailing with Flinders: the journal of seaman Samuel Smith, Nth. Adelaide, S. Aust.: Corkwood Press.

Moore, D. T., T. G. Vallance and E. W. Groves (2001) Nature's Investigator: The diary of Robert Brown in Australia, 1801-1805, Canberra: Australian Biological Resources Study.

Mulvaney, J. (1994) The search for Collet Barker of Raffles Bay, State Library Occasional Papers No. 44, Darwin: State Library of the Northern Territory.

Mulvaney, J. and N. Green (1992) Commandant of Solitude: The journals of Captain Collet Barker 1828-1831, Melbourne: Miegunyah Press.

Mulvaney, J. (1994) The search for Collet Barker of Raffles Bay. State Library Occasional Papers No. 44.Darwin: State Library of the Northern Territory.

Overweel, J. (2002) Keep Them Out! Early Nineteenth Century English and Dutch rivalry in eastern Indonesia and Australia, and the founding of Merkus-oord, <http://www.papuaweb.org/dlib/_sejarah.html> [Viewed 15 September 2011].

Palmer, L. (2007) 'Negotiating the ritual and social order through spectacle: the (re)production of Macassan/Yolyu histories', Anthropological Forum: A journal of social anthropology and comparative sociology, 17 (1), pp. 1-20.

Pym, A. (1998) Method in Translation History, Manchester: St Jerome.

Reid, B. (2007) 'Convict labour in north Australia's colonial settlements: shifting attitudes', Journal of Northern Territory History, 18, pp. 1-10.

Reece, R. (1992) 'The Australasian career of George Windsor Earl', Journal of Northern Territory History, 3, pp. 1-23.

Roland, R. A. (1999) Interpreters as Diplomats: A diplomatic history of the role of interpreters in world politics, Ottawa: University of Ottawa Press.

Rundle, C. (2011) 'History through a translation perspective', in A. Chalvin, A. Lange and D. Monticelli (eds), Between Cultures and Texts. Itineraries in translation history/Entre les cultures et les textes. Itinéraires en histoire de la traduction, Frankfurt Am Main: Peter Lang, pp. 33-43.

Saldin, M. D. (2003) 'Banishment of the first Ceylonese family to Australia', Sunday Island, 12 January. 
Searcy, A. (1907) In Australian Tropics, London \& Palung: Kegan Paul \& Trubner.

Searcy, A. (1912) By Flood and Field: Adventures ashore and afloat in north Australia, London: G. Bell \& Sons Ltd.

Spillett, P. (1972) Forsaken Settlement: An illustrated history of the settlement of Victoria, Port Essington, north Australia, 1838-1849, Melbourne: Lansdowne.

Stell, G. 2007. From Kitaab-Hollandsch to Kitaab-Afrikaans: The evolution of a non-white literary variety at the Cape (1856-1940). Stellenbosch Papers in Linguistics 37: 89-127.

Thomas, P. S. (2012) 'Oodeen, a Malay interpreter on Australia's frontier lands', Indonesia and the Malay World, 40 (117), pp. 122-42.

Toner, P. (2000) 'Ideology, influence and innovation: the impact of Macassan contact on Yolngu music', Perfect Beat:The Pacific Journal of Research into Contemporary Music and Popular Culture, 5 (1), pp. 22-41. 